UDK 528.422

\title{
SKAITMENINIO RELJEFO MODELIO SUDARYMAS IR TOBULINIMAS GEOSTATISTINIAIS METODAIS
}

\author{
Algirdas Kumetaitis \\ Geodezijos ir kadastro katedra, Vilniaus Gedimino technikos universitetas, \\ Saulètekio al.11,LT-10223Vilnius-40,Lietuva, el.paštas: Algirdas.Kumetaitis@bite.lt
}

Iteikta 200312 21, priimta 20040210

\begin{abstract}
Santrauka. Straipsnyje analizuojami skaitmeninio reljefo modelio sudarymo ir tikslumo ívertinimo metodai. Modeliuojant paviršių stačiakampio rastro modeliu, didžiausias tikslumas (vidutinè kvadratinè paklaida $m_{f}=3,03 \mathrm{~m}$ ) pasiektas sudarant skaitmeninį reljefo modelị (SRM) universaliojo krigingo metodu. Palyginus paviršiaus modelius, sudarytus taikant netaisyklingą trikampių tinklą $(T I N)$, buvo gauti analogiški rezultatai $\left(m_{f}=3,07 \mathrm{~m}\right)$. Sudarant didesnès teritorijos skaitmeninius paviršiaus modelius didesniam tikslumui pasiekti siūloma suskaidyti nagrinėjamą teritoriją, skirstant paviršių pagal reljefo įvairovę ir žemėnaudos tipą bei kiekvienai šių teritorijų eksperimentiniu būdu parenkant tinkamiausią paviršiaus modeliavimo metodą. Straipsnyje pateikiama, kad geriausių rezultatu pasiekiama, kai SRM vertinamas ne tik pagal pavienius aukščiu taškus, bet ir pagal eksperimentini paviršiaus modelio fragmentą, sudarytą iš tikslesnių aukščių duomenų. Modeliuojant paviršiu, ivertinamas ne tik sudaromo modelio tikslumas, bet ir pradinių duomenų tikslumas.
\end{abstract}

Raktažodžiai: skaitmeninis reljefo modelis, geostatistinis paviršiaus modeliavimas, universalusis krigingas.

\section{Ivadas}

Geostatistinis paviršiaus modeliavimas - santykinai nauja paviršiaus modeliavimo šaka. Taikomi ne tik sudètingi paviršiaus modeliavimo algoritmai, bet ir statistiniai matavimo duomenų apdorojimo metodai kartu su ekspertinèmis sprendimu paramos sistemomis, pagristomis daugiakriterinès duomenų analizès metodais. Randamos kintamujų, esančių tarp atsitiktinai pasirinktu ir išmatuotų paviršiaus taškų, reikšmès. Pagalbiniai kintamieji aprašo geografini taškų pasiskirstymą $[1,2]$. Modeliuojamas plotas, paviršiaus forma, orientacija ir erdvinis išsidèstymas - pagrindinès charakteristikos, turinčios itakos, skaičiuojant nežinomus paviršius. Keičiantis bet kuriai iš šių charakteristikų, keisis ir nežinomosios reikšmès. Pagalbiniai kintamieji parenkami, modelio parametrai nustatomi, skaičiavimai atliekami taip, kad tiriamo paviršiaus kitimą būtų galima pavaizduoti horizontalèmis.

Straipsnyje nagrinėjami geostatistiniai paviršiaus modeliavimo metodai. Sudarytas skaitmeninis reljefo modelis lyginamas su rezultatais, gautais modeliuojant paviršių kaip netaisyklingą trikampių tinklą.

\section{Lietuvos teritorijos skirstymas pagal reljefo tipa}

Lietuvos teritorijos reljefo modelis buvo sudarytas ANUDEM metodu [3]: interpoliuojant reljefo modeli, panaudojami taškiniai, linijiniai ir plotiniai duomenys. Tyrimas parodè, kad reljefo paklaidos visoje Lietuvos teritorijoje pasiskirsčiusios netolygiai ir priklauso nuo reljefo tipo. Šiam tyrimui buvo sudarytas reljefo kintamumo žemėlapis (1 pav.), kur skirtingomis spalvomis pavaizduotas reljefo kitimas. Žemèlapis sudarytas pagal sveikosiomis reikšmèmis nusakomo reljefo modelį. Tyrimui atlikti paviršius buvo suskaidytas i $300 \mathrm{~m}$ dydžio kvadratus ir analizuota, kiek skirtingu ląstelių reikšmiu yra paviršiaus imtyje. Pagal skirtingu aukščiu reikšmių skaičių reljefas buvo suskirstytas i 4 kategorijas. Tuomet apskaičiuotos paklaidos kiekvienoje reljefo kategorijoje (1 lentelè). Matome, kad didžiausios paklaidos $(3,38 \mathrm{~m})$ teritorijų, kur didžiausi reljefo pokyčiai. Mažiausios - teritoriju, kur aukščiu reikšmiu ivairovė mažiausia.

1 lentelè. Skirtingų reljefo kategorijų vidutinès kvadratinès paklaidos kitimas

Table 1. Variation of standard errors of DEM in different type of surface

\begin{tabular}{|c|c|c|c|c|c|}
\hline Kodas & Reljefo tipas & $\begin{array}{c}\text { Aukščių reikšmių } \\
\text { skaičius, } \\
\text { vnt. }\end{array}$ & $\begin{array}{c}\text { Vidutine reljefo } \\
\text { paklaida, } \\
\mathrm{m}\end{array}$ & Mediana & $\begin{array}{c}\text { Vidutiné kvadratinė } \\
\text { reljefo paklaida } \\
m_{f}, \mathrm{~m}\end{array}$ \\
\hline 1 & lyguma & 247 & 0,05 & 0,02 & 2,52 \\
\hline 2 & mažas reljefo pokytis & 290 & 0,96 & 0,49 & 3,07 \\
\hline 3 & vidutinis reljefo pokytis & 290 & 0,46 & 0,47 & 3,27 \\
\hline 4 & didelis reljefo pokytis & 84 & 0,79 & 1,71 & 3,39 \\
\hline & Iš viso & 911 & 0,54 & 0,35 & 3,24 \\
\hline
\end{tabular}




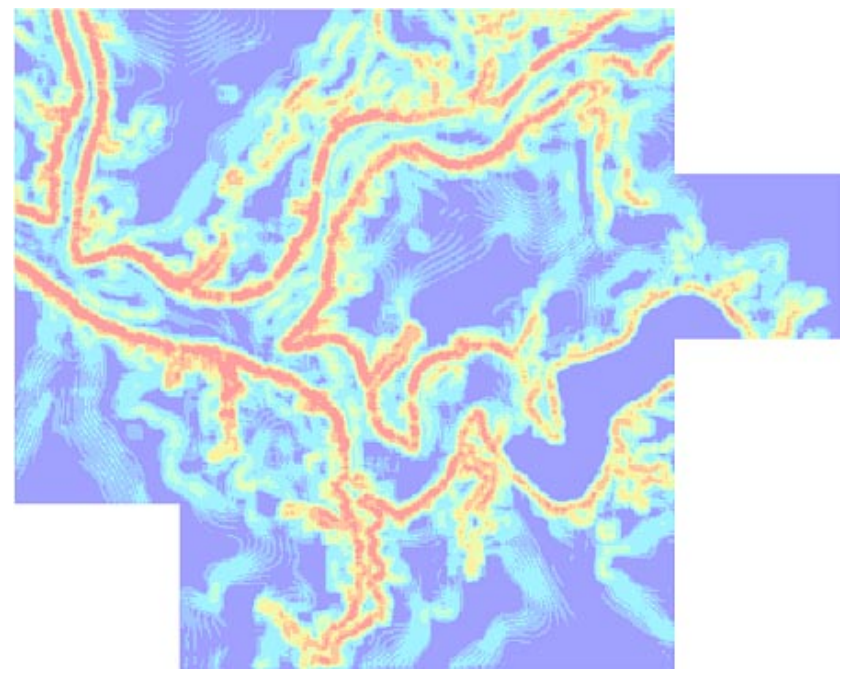

1 pav. Reljefo kintamumo žemèlapis

Fig 1. Terrain surface variability map

Siekiant išsiaiškinti kitas paklaidų kaupimosi tendencijas, buvo atliktas tyrimas - nagrinèta, ar vidutinès paklaidos dydis priklauso nuo žemènaudos rūšies. Tam visa Lietuvos teritorija buvo suskirstyta i 9 skirtingas žeménaudos kategorijas (2 lentelè). Nepastebejjus koreliacijos tarp reljefo paklaidų dydžio ir žemėnaudos tipų, buvo analizuojamas kontrolinių taškų išsidèstymas ir tašku skaičius kiekvienoje žeménaudos kategorijoje bei šių žemėnaudos tipų teritorijų plotai.

Tyrimas parodè, kad kai kurių žemėnaudų kategorijų teritorijose kontrolinio paviršiaus modelio taškai išdèstyti netinkamai ir juc tankumas nepakankamas. Kadangi skirtingu žeménaudos kategorijų plotai Lietuvos teritorijoje nevienodi (labai mažą jos plotą užima upių slèniai), todèl tolygiai išsidèstę kontroliniai taškai šiuose plotuose reljefo beveik neatspindi (2 pav.). Norint ištirti reljefo modelio vidutinių kvadratinių paklaidų dydžio priklausomybę nuo žemėnaudos tipo, reikalingas detalus paviršiaus modelis, sudarytas parinkus optimalų metodą.

\section{Optimalių paviršiaus modeliavimo parametrų parinkimas}

Ieškant optimalaus metodo pasirinktos teritorijos reljefui modeliuoti buvo sudaryta 10 eksperimentiniu skaitmeniniu paviršiaus modelių. Trys modeliai buvo sudaryti paviršių suskirstant trikampiais, keturi modeliai - krigingo metodais, atliekant reljefo tikslumo tyrimą. Iš reljefo modelio tikslumo tyrimų paaiškejjo, kad sudarant skaitmenini paviršiaus modeli, reikia taikyti trupmenines paviršiaus parametrų reikšmes. Taikant sveikąsias paviršiaus modelio parametrų reikšmes, gautas mažesnio tikslumo paviršiaus modelis. Apie didžiausią sveikuju reikšmių tipo paviršiaus modelio trūkumą bylojo nubraižyti raižyto paviršiaus vietoviu profiliai (3 pav.).

Iš 3 pav. matome, kad paviršiaus kontūrai sveikuju reikšmių tipo modelyje linksta terasomis. Todèl straipsnyje rekomenduojama atliekant skaičiavimus, kuriuose būtina remtis sveikuju reikšmių tipo paviršiaus modeliu, taikyti toki šio tipo modelị, kurio ląsteliu reikšmès išreikštos sveikaisiais decimetrais, centimetrais arba milimetrais.

Remiantis žeménaudos kategorijų sluoksnio žemèlapyje informacija, tirta, ar paklaidos dydis priklauso nuo žemènaudos nagrinèjamame plote tipo, ar skirtingi modeliavimo metodai yra pranašesni, modeliuojant paviršių skirtingo reljefo ir skirtingu žemėnaudų sluoksnių teritorijose. Tyrimas parodé, kad paviršiaus modelio tikslumas mažèja, kai vietovès raižytos, ir yra tiesiog proporcingas paviršiaus nuolydžiams tiriamoje teritorijoje. Nustatyta, kad geriausi rezultatai gaunami modeliuojant reljefą universaliojo krigingo metodu. Šio modelio paviršiaus profilis mažiausiai skiriasi nuo didesnio tikslumo 1:10 000 reljefo profilio (4 pav.).

2 lentelè. Vidutinès kvadratinès reljefo paklaidos kitimas skirtingo žemėnaudos tipo plotuose

Table 2. Variation of standard errors of DEM in aereas of different land use categories

\begin{tabular}{|c|c|c|c|c|c|}
\hline Kodas & Žemėnaudos tipas & $\begin{array}{c}\text { Kiekis, } \\
\text { vnt. }\end{array}$ & $\begin{array}{c}\text { Vidurkis, } \\
\mathrm{m}\end{array}$ & Mediana & $\begin{array}{c}\text { Vidutinè } \\
\text { kvadratine } \\
\text { paklaida } \\
m_{f}, \mathrm{~m}\end{array}$ \\
\hline 1 & daugiaaukščiai statiniai & 247 & 0,05 & 0,02 & 2,52 \\
\hline 2 & miestas & 290 & 0,96 & 0,49 & 3,07 \\
\hline 3 & užstatyta teritorija & 84 & 0,79 & 1,71 & 3,39 \\
\hline 4 & miškai & 290 & 0,46 & 0,47 & 3,27 \\
\hline 5 & sodai & 47 & 0,71 & $-0,25$ & 3,77 \\
\hline 7 & dirbama žemé & 338 & 0,36 & 0,58 & 3,42 \\
\hline 9 & upès & 14 & 5,38 & 4,95 & 1,31 \\
\hline 10 & ežerai & 8 & $-0,26$ & $-1,02$ & 3,51 \\
\hline \multirow[t]{2}{*}{100} & upių ir ežerų krantai & 237 & 0,54 & 0,06 & 3,44 \\
\hline & Iš viso & 1555 & 0,54 & 0,35 & 3,24 \\
\hline
\end{tabular}




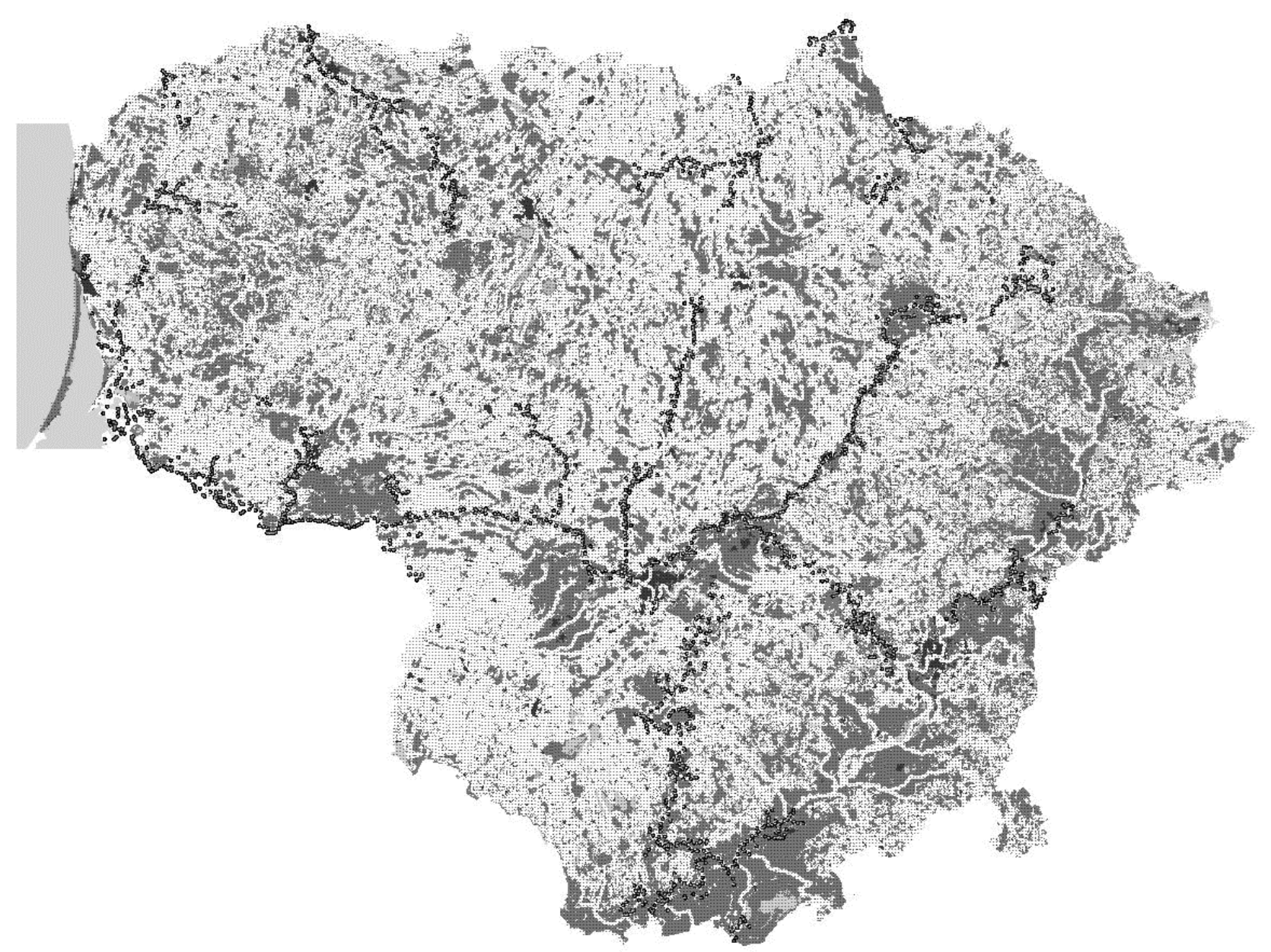

2 pav. Kontrolinių aukščio taškų išsidėstymas žemėnaudos kategorijų sluoksnyje Fig 2. Distribution of height points in land use layer

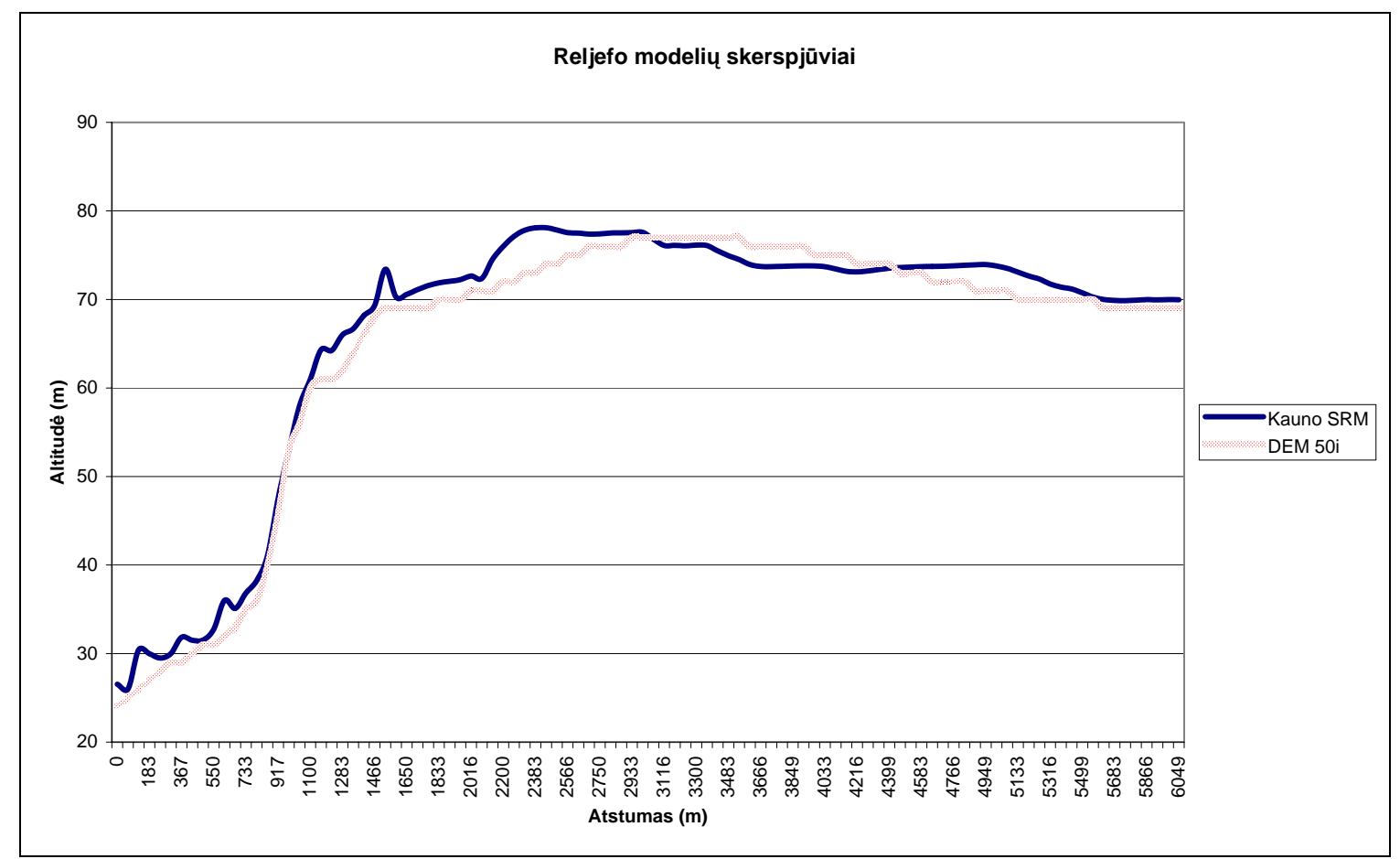

3 pav. Sveikujų reikšmių tipo paviršiaus modelio profilis

Fig 3. Profile of integer DTM 
3 lentelè. Statistiniai reljefo modeliu paklaidų parametrai

Table 3. Statistical parameters of DTM errors

\begin{tabular}{|c|c|c|c|c|c|c|c|c|}
\hline $\begin{array}{l}\text { Paviršiaus } \\
\text { modeliavimo } \\
\text { metodas }\end{array}$ & \begin{tabular}{|c|}
$\begin{array}{c}\text { Kontroli- } \\
\text { nių tašku } \\
\text { sk. }\end{array}$ \\
\end{tabular} & $\begin{array}{c}\text { Vidurkis, } \\
\mathrm{m}\end{array}$ & $\begin{array}{c}\text { Dispersija, } \\
\mathrm{m}\end{array}$ & $\begin{array}{c}\text { Vidutine } \\
\text { kvadratine } \\
\text { paklaida, } \\
m_{f}, \mathrm{~m}\end{array}$ & $\begin{array}{c}\text { Minimumas, } \\
\mathrm{m}\end{array}$ & $\begin{array}{l}\text { Maksimu- } \\
\text { mas, } \\
\text { m }\end{array}$ & $\begin{array}{l}\text { Asimetrijos } \\
\text { koeficientas }\end{array}$ & $\begin{array}{c}\text { Eksceso } \\
\text { koeficientas }\end{array}$ \\
\hline DISJ_KRIG & \multirow{10}{*}{1555} & 0,44 & 10,45 & 3,23 & $-9,37$ & 9,57 & $-0,08$ & 1,73 \\
\hline H2OOO & & 0,54 & 10,47 & 3,24 & $-9,71$ & 9,99 & 0,64 & 4,92 \\
\hline$I D W$ & & 0,47 & 10,54 & 3,25 & $-8,83$ & 9,71 & $-0,02$ & 0,51 \\
\hline ORKRIG & & 0,50 & 11,12 & 3,33 & $-11,32$ & 9,74 & $-1,38$ & 2,98 \\
\hline$R B F$ & & 0,60 & 11,68 & 3,42 & $-8,73$ & 19,14 & 10,34 & 21,90 \\
\hline$S I M P \_K R I G$ & & 0,38 & 11,08 & 3,33 & $-9,34$ & 9,84 & $-0,35$ & 2,04 \\
\hline TIN_HARD & & 0,53 & 9,41 & 3,07 & $-9,94$ & 9,08 & 0,75 & 2,27 \\
\hline TIN_PTS & & 0,54 & 9,39 & 3,06 & $-9,91$ & 9,11 & 0,84 & 2,25 \\
\hline TIN_SOFT & & 0,53 & 9,41 & 3,07 & $-9,94$ & 9,08 & 0,75 & 2,27 \\
\hline UNIV_KRIG & & 0,50 & 9,18 & 3,03 & $-8,56$ & 9,84 & 1,23 & 2,61 \\
\hline
\end{tabular}

Reljefo modeliụ skerspjūviai

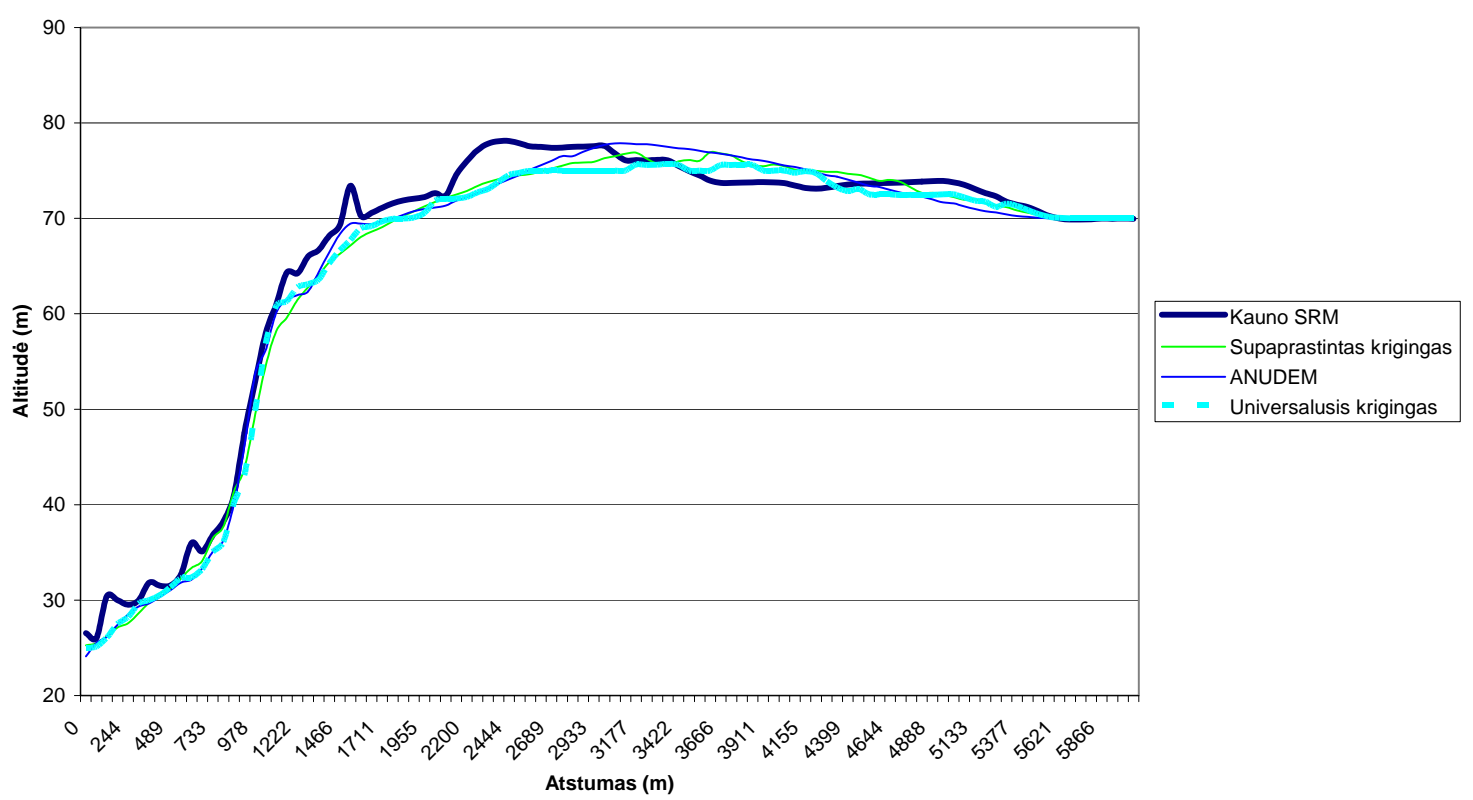

4 pav. Rastrinių paviršiaus modeliu profiliai

Fig 4. Profiles of gridded surface

\section{SRM tikslinimas taikant netaisyklingą trikampių tinklą (TIN)}

Paviršiaus modelio, pagrịsto netaisyklingu trikampių tinklu (TIN), taikymas sudarant tikslius skaitmeninius paviršiaus modelius yra perspektyvi paviršiaus modeliavimo kryptis [4]. Šio modelio pranašumas - netaisyklinga trikampè struktūra (5 pav.), savo forma tiksliai atkartojanti natūralius paviršius. Taip pat netaisyklinga struktūra leidžia išvengti parametrų pertekliaus lygumų teritorijose ir perteikti visą raižyto reljefo plotų reljefo sudettingumą. Kitas TIN privalumas galimybè tiesiogiai, netaikant interpoliavimo metodų, panaudoti pradinius matavimų duomenis paviršiaus modeliui sudaryti [5]. TIN metodu sudaryti paviršiaus modeliai nuo sudarytujų universaliojo krigingo metodu (6 pav.) tikslumu atsilieka labai mažai (3 lentelè). Vertinant ivvairias paviršiaus kategorijas, matomas TIN modelio pranašumas kitų paviršiaus modeliavimo metodų atžvilgiu teritorijų, kur yra didesnè reljefo įvairovè.

Didelis skaidymo trikampiais privalumas galimybė naujus paviršiaus duomenis tiesiogiai įtraukti i paviršiaus modelị, perskaičiuojant ne visą tinklą, o tik aktualias vietas [6]. Taip pat paviršiui sudaryti galima tiesiogiai panaudoti ne tik aukščių taškus, bet ir plotus su tam tikromis aukščių reikšmėmis (hidrografijos objektu) bei horizontales. 


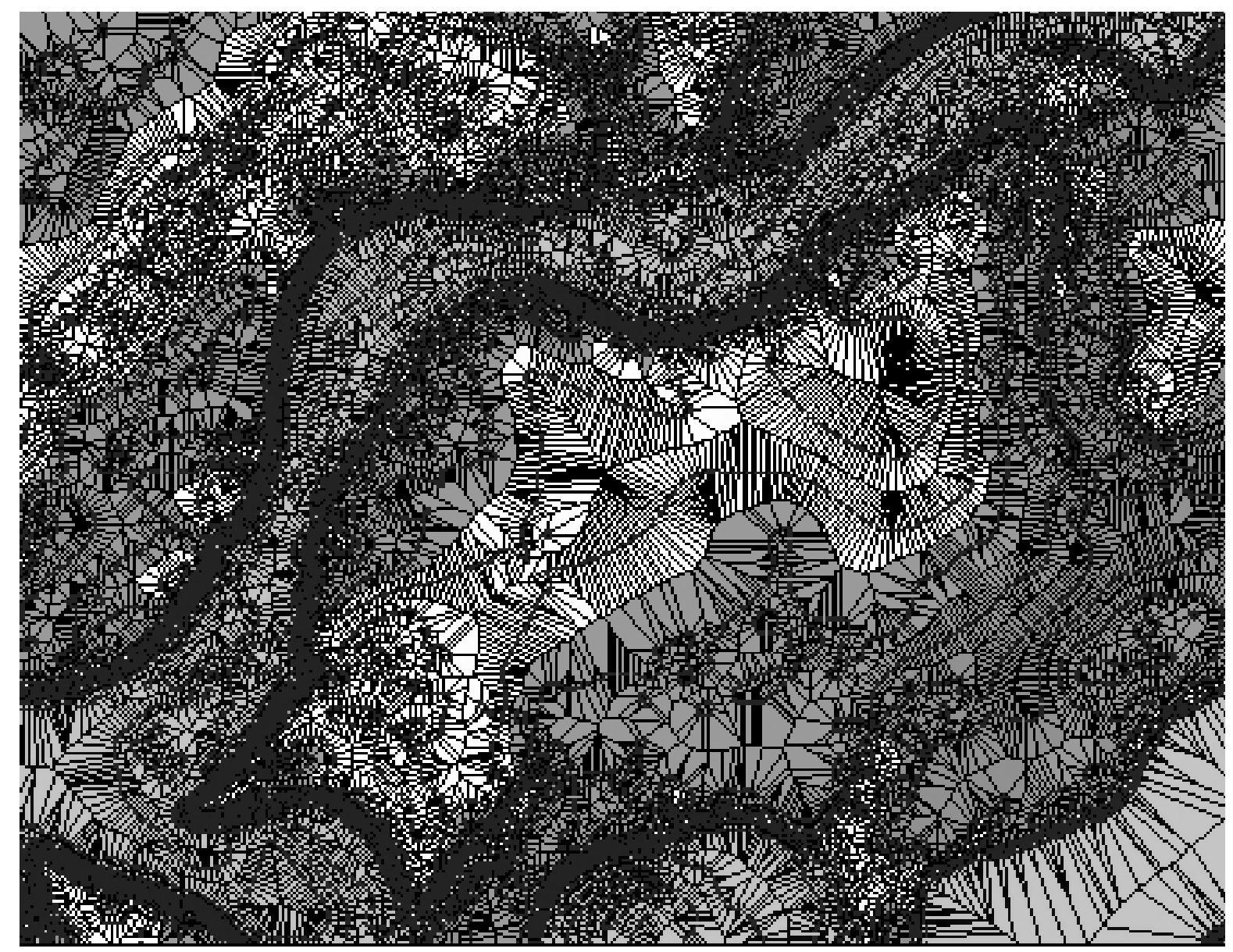

5 pav. Delauney trianguliacija

Fig 5. Delauney trianguliation

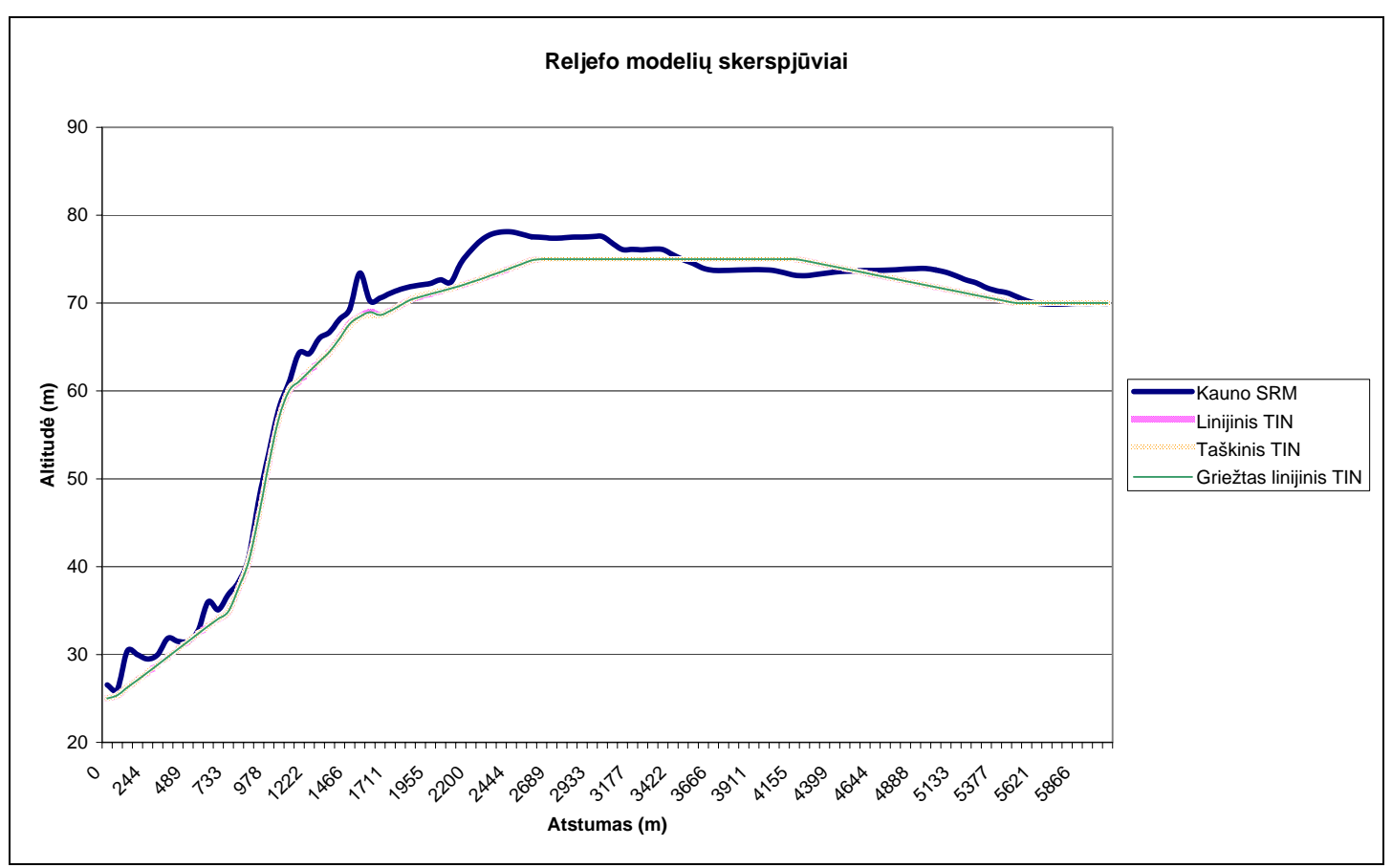

6 pav. TIN paviršiaus modeliu profiliai

Fig 6. Profiles of TIN surface 


\section{Išvados}

1. Modeliuojant paviršių pagal stačiakampio rastro modelį, didžiausias tikslumas pasiektas sudarant SRM universaliojo krigingo metodu $\left(m_{f}=3,03 \mathrm{~m}\right)$. Paviršių modeliuojant TIN metodu gauti analogiški rezultatai $\left(m_{f}=3,07 \mathrm{~m}\right)$.

2. Sudarant didesnès teritorijos skaitmeninius paviršiaus modelius, didesniam tikslumui pasiekti siūloma nagrinèjamą teritoriją suskaidyti i tam tikras teritorijas, skirstant paviršių pagal reljefo ivvairovę ir žemènaudos tipą bei kiekvienai iš šių teritoriju eksperimentiniu būdu parenkant tinkamiausią paviršiaus modeliavimo metoda.

3. Paviršiaus tikslumas turi būti vertinamas atsižvelgiant i visumą veiksnių: bendrąsias ir tam tikrų teritorijų aukščiu taškų paklaidas, tęstinio paviršiaus modelio paklaidas, reljefo skerspjūvių tikslumą.

4. Geriausi rezultatai pasiekti, SRM vertinant ne tik pagal pavienius aukščiu taškus, bet ir pagal eksperimentini paviršiaus modelio fragmentą, sudarytą iš didesnio tikslumo aukščių duomenų.

\section{Literatūra}

1. Isaaks, E. H. and Srivastava, R. M. An Introduction to Applied Geostatistics. Oxford: Oxford University Press, 1989. $592 \mathrm{p}$.

2. Davis, J. Statistics and data analysis in geology. New York: Wiley, 1986. 564 p.

3. Hutchinson, M. F. ANUDEM version 4. 6. 3. Canberra, Centre for Resources, Environmental Studies, Australian National University, 2001.

http://cres.anu.au/software/anudemtxt.html

4. Rocchini, C.; Cignoni, P.; Ganovelli, F.; Montani, C.; Pingi, P.; Scopigno, R. Marching Intersections: an Efficient Resampling Algorithm for Surface Management. International Conference on Shape Modeling and Applications (SMI 2001). Genova, Italy, May 7-11, 2001, p. 296-305.

5. Environmental Systems Research Institute (ESRI), Inc. Arc/Info, Surface Modelling with TIN. User's Guide. Redlands, CA: ESRI, 1992. $431 \mathrm{p}$.

6. Little, J. J., Shi, P. Structural lines, TINs, DEMs. Proc. of International Symposium on Spatial Data Handling 8th, July 11-15, Vancouver BC, 1998, p. 627-636. 